\author{
AN ARTICLE \\ Submitted in Partial Fulfillment of the Requirements \\ for the Degree of SarjanaPendidikan
}

By:

ARYOKTA ISMAWAN

Registration Number: 2133121011

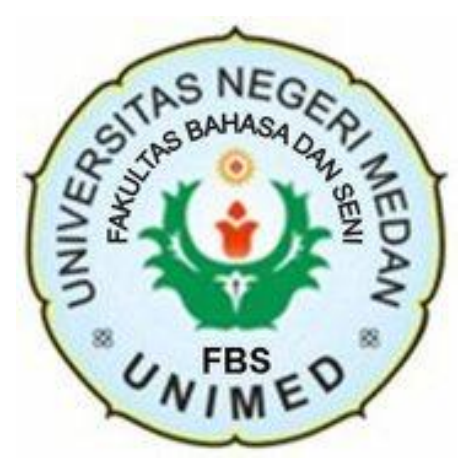

ENGLISH AND LITERATURE DEPARTMENT

FACULTY OF LANGUAGES AND ARTS

STATE UNIVERSITY OF MEDAN

2018 
ARTIKEL

\title{
CARTOON STORY MAKER AS THE DEVELOPED LEARNING MEDIA IN WRITING DESCRIPTIVE TEXT FOR JUNIOR HIGHSCHOOL STUDENTS
}

\author{
Disusun dan Diajukan oleh: \\ Aryokta Ismawan \\ NIM. 2133121011
}

Telah diverifikasi dan dinyatakan memenuhi syarat

Untuk diunggah pada jurnal online

Medan, $\quad$ Mei 2018

\section{Menyetujui}
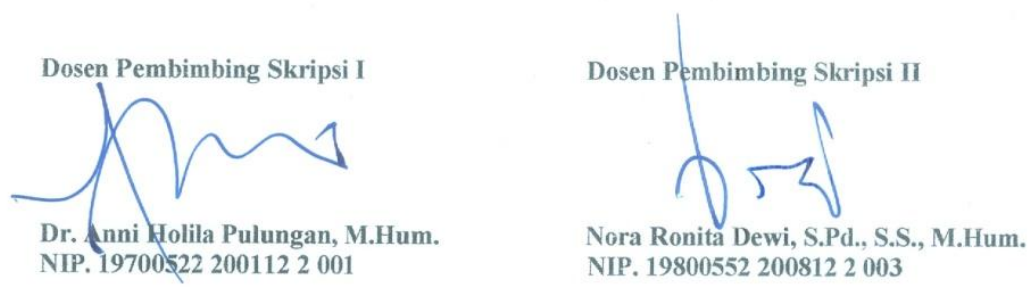

Ka. Program Studi

Pendidikan Bahasa Inggris

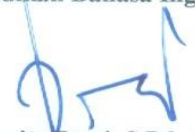

Nora Ronita Dewi, S.Pd., S.S., M.Hum.

NIP. 198005522008122003 


\title{
CARTOON STORY MAKER AS THE DEVELOPED LEARNING MEDIA IN WRITING DESCRIPTIVE TEXT FOR JUNIOR HIGHSCHOOL STUDENTS
}

\author{
*Aryokta Ismawan \\ **Anni Holila Pulungan \\ **Nora Ronita Dewi \\ ABSTRACT
}

The aim of this study was to develop learning media in Writing Descriptive Text for Grade VIII of Junior Highschool Students. This study was conducted by using Research and Development (R\&D) design through six stages; gathering information and data, analyzing data, designing materials, validating by experts, revising, and final product.. The subject of the study was Grade VIII of SMP N 3 LubukPakam. The data were gathered by administering interview to English teacher and distributing questionnaire to 30 respondents to get the students' needs. The interview and questionnaire results prove that the students needs English learning media which can motivate the students to understand about the descriptive writing. The product has been validated by experts. The result of the product was videos that contain audio-visual media to be used in mastering the descriptive text writing.

Keywords: Cartoon Story Maker, Descriptive Text, Research and Development $(R \& D)$

\footnotetext{
*Graduate Status

**Lecturer Status
} 


\title{
INTRODUCTION
}

\author{
Background of the Study
}

In learning English, writing is one of the skill which needs more concern among others because writing deals with mixture of idea, vocabulary, and grammar. Different from speaking, writing is more difficult and also complicated to acquire because there are many aspects related to writing which need to be mastered such as organization, mechanics, and grammar.

Though writing is an essential part in English that the students have to master, students often face difficulties in writing including developing ideas, unenthusiastic student's attitude to the lesson, difficulty in grammar and lack of vocabularies. Harmer (2004:31) stated "Writing encourage students to focus on accurate language use and because they think as they write, it will provoke language development as they resolve problems which the writing puts into their minds". In writing English, students have to consider the grammar to make their writing understandable. Therefore, in arranging words by words to become one good sentence, the text also require different tense according the text they are going to write.

According to the syllabus of Curriculum 2013, one of the genres that students learned in Junior High School is descriptive text.A descriptive text is a text that gives a picture in words or the description about sensory experience on how something looks, sounds, tastes. It means that the students use their imagination and knowledge in their writing. 
Based on the preliminary observation of grade VIII of SMP Negeri 3 Lubuk Pakam that was by interviewing the English teacher about the students' writing especially in descriptive text. The teacher told that most of the students are having difficulties in transfering their ideas, even in arranging it into writing.

In teaching learning process, the researcher also found someproblems. Including the students' attitude in which they feel bored and not interested in learning because of the unchangable method from the teacher. The researcher found earlier that the teacher used lecturing method. Another problem is students did not understand what the teacher has explained. The media that being used also is just printed pictures got from the internet and colorful papers, which is oldfashioned enough, without any other media that support the teaching - learning process. Moreover, the explanation given by the teacher sometimes does not relate to the media that being used. So that, it makes the students confused about the material and do not have clear information about it.

The Information and Communication Technology (ICT), therefore, can be extensively used to support classroom activities, group assignment, and thereby promote student-centered learning. In this case, Cartoon Story Maker, an interesting useful application for students, comes up as a solution in helping the teacher achieve the goal of the writing skill.

Cartoon Story Maker isa simple program that let users to rapidly create 2D cartoon stories with conversations, dialogues, and different backgrounds. Some supporting features that available are people characters, background settings, and dialogue bubbles. Locations and characters can be imported from any files and downloaded materials. As stated from Languages Online, the Cartoon Story 
Makerhas been designed with a focus on applying language learning. It is easy to use with simple controls so users spend less time manipulating tools and more time on the language. Not only that, Cartoon Story Maker also can be used as a medium for students' writing in a number of modes: conversation, narrative, persuasive or informative, descriptive, to revise a language topic, as an assessment task, to practice pronunciation and spelling, as a collaborative task and as a window into culture from where the students come.

Hence, based on the explanation above, the researcher is interested in conducting this research in order to know whether the students have a better understanding and scores through the using of Cartoon Story Maker.

\section{REVIEW OF LITERATURE}

Writing is one of the skills which the students must be optimally wellmastered. Through writing, the students can deliver their ideas, thoughts and experiences. Moreover, they also need a good writing skill in order to express their feeling, need and desire in a understandable written form.

Brown (2001: 336) states that writing is a thinking process. Furthermore, he said that writing is not an easy way to transmit a message just like other skills because there's a complex process in producing one final product. Writing, in fact, allows the writer to freely share their thoughts, feelings, and perceptions.

Dirgeyasa (2016: 56) remarks that descriptive genre is the the way to describe or illustrate someone or something in order to have visual appeareance of it.Gerot and Wignell (1995: 208) define descriptive text as a kind of text which is aimed to describe a particular person, place or things. In other words, descriptive text has a purpose to describe about what a person looks and acts like, what a 
place looks like, and what an object looks like, e.g.; (a) describe a special place and explain why it is special; (b) describe the most important or particular person; (c) describe the animal's habitat.

Cartoon Story Maker is a simple software or application that allows teacher to create $2 \mathrm{D}$ cartoon stories with conversations, dialogues and different background based on the learning material which the teacher will be taught in class. This software is really compatible to use in any type of processor of the computer. The software also can be categorized as a light weight program because it doesn't take so many memory in the computer.

Languages Online states that Cartoon Story Maker has some supporting features that can be used, such as people characters, background settings, and dialogue bubbles. The locations and characters also can be imported from any files or downloaded materials based on the needs of the learning material. This software also easy to use because the design are really simple. It has been designed with a focus on applying the language learning, so that the designer of the learning material spend less time manipulating the tools and have more time on the language itself.

Cartoon Story Maker also can be an effecient and effectivemedia in teaching learning. The reason is because Cartoon Story Maker covers all of the media that the teacher needs in teaching, which are consist of pictures, text, and audio. It can be shown with just one software. Moreover, the software is light weight and easy to use, it has already complex tools to create a good learning material. Maharsi (2016) based on her findings in her research stated that:

"The use of Cartoon Story Maker is believed to improve students in terms of affective domain, autonomy, and awareness. Using the Cartoon Story 
Maker application is perceived as fun and interesting so that the processes of writing stories are enjoyable."

For that matters above, it can be said that Cartoon Story Maker is an approriate and an exact learning media for the teacher to use in the classroom. Cartoon Story Maker contents audio and visual is also a suitable media for Junior High School because it increases the students' interest and motivation in teaching and learning process. By using Cartoon Story Maker as teaching media, the students will get helped in getting the idea to write and to use an appropriate vocabulary that can be seen through it.

\section{RESEARCH METHODOLOGY}

This research was conducted by usingeducational Research and Development ( $\mathrm{R} \& \mathrm{D})$ research method that had a function to develop a new educational product based on the needs analysis. The R \& D research method that being used for this research was proposed by Borg and Gall (2003).

This sudy was applied in SMP Negeri 3 LubukPakam which is located in J1. SundaBakaranBatu. The subject of this study was the grade VIII students of SMP Negeri 3 LubukPakam.In collecting the data, the researcher applied the combination of two strategies, using questionnaires and interview. The interview is given to the teacher, and some students to seek information about the problem that they face in order to know what media that should be applied to solve the problem.

The researcher accumulated the data by using qualitative and quantitative approach. The qualitative data was accumulated from the questionnaires gotten from the students and interview given to the teacher and some students. While the 
quantitative data was accumulated from the questionnaires in the form of number and percentage. In the data analysis, these two forms would be the references that being used.

The research was applied by adapting Borg and Gall's research and development theory (2003) with some modifications which becomes 6 steps of $\mathrm{R}$ \& D cycle. Borg and Gall (2003) proposed the R \& D cycle in a connecting

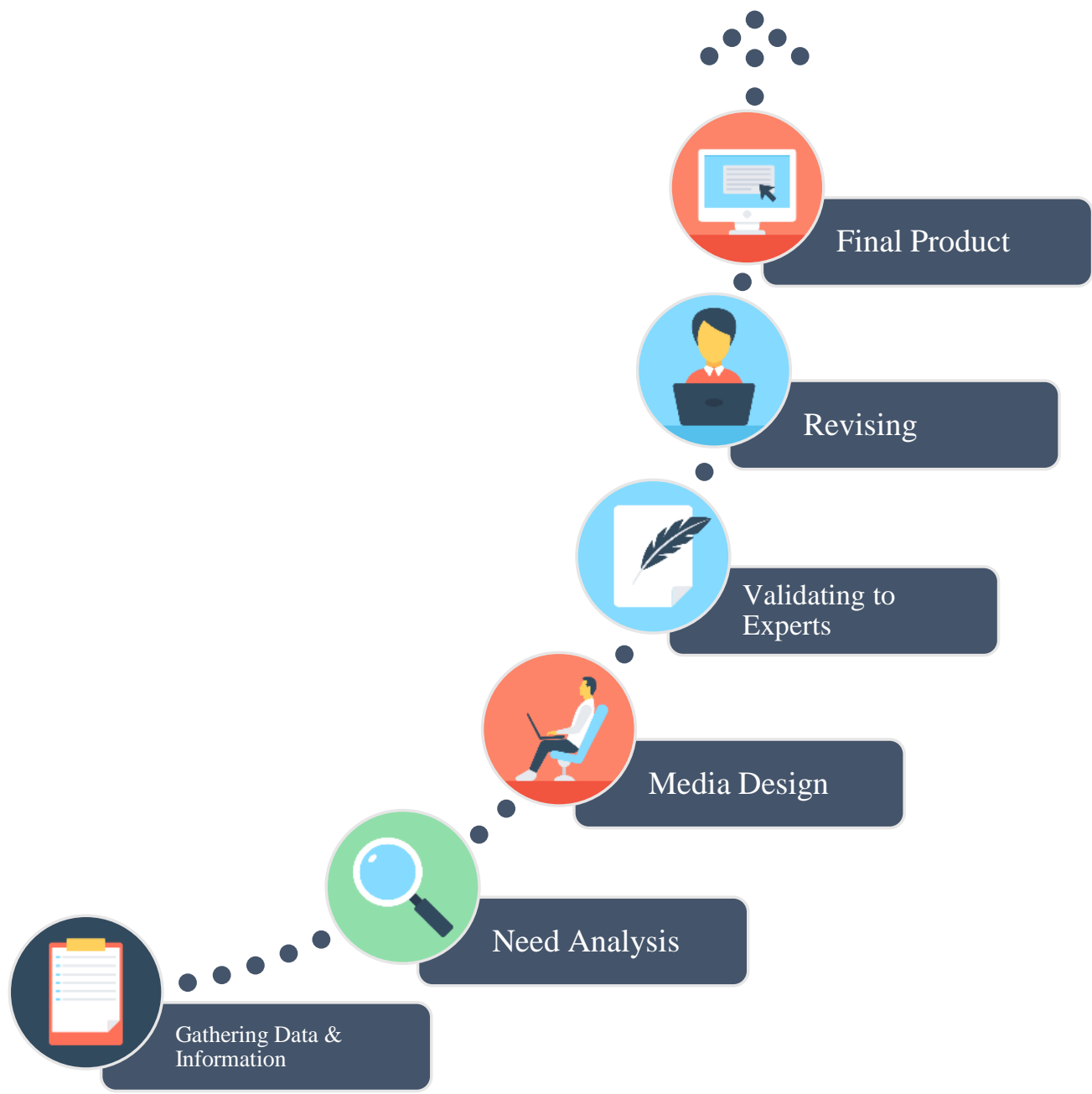

structure which in the end of the cycle produced a new product in the form of writing media. 
Figure 1.1. Research and Development cycle by Borg and Gall (2003).

\section{RESEARCH FINDINGS}

This study is aimed to create a learning media based on the students and also the teacher needs. The researcher using the Cartoon Story Maker template and also some supporting characters got from the internet to make the learning media. The learning media that made by the researcher done in several steps. The step planning consists of preparing the material, designing the story board, editing the background and finding the characters, adding the background music and also the voiceover.

The data and information were collected from the preliminary observation that done before doing the research. As the result of the observation, the teacher in the eighth grade of SMPN 3 LubukPakam used only book got form the government that was entitled "When English Rings a Bell" and some printed pictures to use them as the media to support the process of descriptive text writing. Since writing was categorized as a difficult learning process, the media that being used was not very interesting to the students and less motivate them to learn how to write in descriptive.

In conducting this research, the second step needed to be completed was doing the needs analysis. The needs analysis was done by giving the grade eighth students questionnaire and were asked to answer some questions.The questionnaire was administered to 30 grade eight students of SMPN 3 LubukPakam. They were given a questionnaire which consisted of 12 questions. 
In order to do the needs analysis, there are three categories that need to be covered, namely necessities, lacks and wants of the learners. The researcher gave an interview to the English teacher of the eighth grade of SMPN 3 Lubuk Pakam. It was conducted to support the results of the questionnaire analysis by the students and also to get the accurate data.

The media that already being developed were validated by experts. Questionnaire sheet was used by the experts to measure whether th elearning media was already appropriate or not.The questionnaire was made based on rating scale. The scale are excellent (5), good (4), fair (3), less (2), very less (1). The expert's questionnaire filled by Dra. Masitowarni Siregar, M.Ed. (English Lecturer in Medan State University) and Amanah, S.Pd., M.Hum (English Teacher in SMPN 3 Lubuk Pakam). They checked the information and components in the learning media, such as color, font, content, and instrument. There were 4 aspects in the experts' questionnaire, they are about linguistic aspect, process aspect, product and content aspect, and layout aspect.

The Result Data of Experts Validationof Cartoon Story Maker

\begin{tabular}{llcc}
\hline No & \multicolumn{1}{c}{ Item Assessed } & $\begin{array}{c}\text { Experts Validation } \\
\text { (Percentages) }\end{array}$ & Criteria \\
\hline 1 & Linguistic Aspect & 92,8 & Excellent \\
\hline 2 & Process Aspect & 92,8 & Excellent \\
\hline 3 & Product and Content Aspect & 93,3 & Excellent \\
\hline 4 & Layout Aspect & 94 & Excellent \\
\hline & An overall assesment & 93,2 & Excellent \\
\hline
\end{tabular}


From the table above, it shows the average score expert's validation form the lecturer and the teacher. They validate the media related the four aspects given by the experts is $93,2 \%$, so the assessment of the indicators is excellent. In general, based on the validation of some experts, these materials were appropriate to be used by the eighth grade students of SMP Negeri 3 LubukPakam.

After revising the media, the final product had been completed. The media was already based on the students' needs and appropriate to be used in the teaching learning process which was able to enhance the students' enthusiasm and achievement.

\section{CONCLUSIONS \& SUGGESTIONS}

After analyzing the data, the researcher draws the conclusion that the students' existing writing media are not interesting, and also the media that being used by the teacher was not effective enough to make the students understand about the descriptive text writing. They find it is difficult to write and make a descriptive text which eventually brings them to be passive learners. They want to have the interesting and effective media which motivate them to learn and write the kind of descriptive text. The solution for them is developing the new writing media. Developing media by using Cartoon Story Maker follow the R \& D phases by Borg and Gall (2003) which is simplified into, (1) Gathering Data and Information; (2) Need Analysis; (3) Design Media; (4) Validate by expert; (5) Revision; (6) Final Product. The score of validation from the validators was $93,2 \%$ and it was categorized as relevant. In means that the media were valid and appropriate to use as learning media for students. 
There were some suggestion given for the consideration the future. For the teacher, teacher should consider the students' needs in choosing the learning media. The learning process can be successfull if the teachermastered in explaining the descriptive text as well as using a learning media that can support them. Then, the teacher also should pay attention to kind of text that will be given to the students. For this reason, a descriptive text about person is really suitable for the teacher to be used in the class, because it represented the daily life experience of the students better than others text given. For the students, they can use the Cartoon Story Maker as a media for them to be used in writing descriptive text. For the next research and development, the testing should be conducted when the students were studying about writing descriptive text in order to get the evaluation more accurately. 


\section{REFERENCES}

Borg, W.R. and Gall, M.D. 2003. Educational Research An Introduction (Revised $E d)$. New York: Longman

Brown, H. D. 2001. Teaching by Principles: An Interactive Approach to Language Pedagogy. Great Britain: Longman.

Dirgeyasa, I Wy. 2016. College Academic Writing: A Genre Based Perspective. Jakarta: Kencana.

Gerrot, L., \&Wignell P. 1995. Making Sense of Functional Grammar. Sydney: Antepodean Educational Enterprises.

Harmer, J. 2004. The Practice of English Language Teaching. New York: Longman.

Maharsi, I. 2016. Finding Connection between Extensive Reading and Story Writing. CakrawalaPendidikan, Vol. XXXV, No. 2, pp. 187-197, June 2016. 